\title{
DEAN'S INTRODUCTION
}

This collection of articles was prepared as part of the University of Calgary's Celebration of its Twenty-Fifth Anniversary in 1991. Although the Law School is even younger (we opened our doors in 1976), members of the Faculty of Law wanted to commemorate this important University milestone with a lasting contribution to legal scholarship. The purpose of this collection is to canvass and record how certain aspects of the discipline of law have changed over that twenty-five year time frame in Alberta and Canada. This final product represents our shared commitment to learning and to the University of Calgary.

All contributors have significant links to and affection for the University of Calgary. Six articles were written by people who are full time faculty members of the Faculty of Law. The remaining three were produced by notable exceptions: John McLaren, the founding Dean of the University of Calgary Law School, who now holds the Lansdowne Chair of Legal History at the University of Victoria; Richard Devlin who spent two productive years with us and currently teaches at Dalhousie; and Susan Blackman, Janet Keeping, Monique Ross and Owen Saunders, all from the Canadian Institute of Resources Law (C.I.R.L.), who jointly authored one of the articles. The Institute is an independent research institute affiliated with the Faculty.

This collection of papers contains a wide ranging and diverse combination of legal scholarship. Anne Stalker addresses the criminal law on self-defence and consent to highlight the curious interrelationship between common law principles and the Criminal Code. Michael Wylie gives an overview of the turbulent times encountered by Alberta's deposit-taking industry during the relevant twenty-five year time frame. He examines the extent to which consumers have been and currently are protected when a deposit-taking institution collapses and how those consumer protection provisions have been justified. C.I.R.L.'s article explains how natural resources management issues have played an important role in federal-provincial relations and how Alberta has taken a distinctive position within the past quarter of century. John McLaren offers a historical perspective by showing how legal history has undergone a transformation during the past twenty-five years, from a scholarly void to a lively branch of social and intellectual history, particularly due to the efforts of Albertan legal historians. While Richard Devlin's work on "Mapping Legal Theory" provides an overview of legal theory, many of the other articles embrace or embody jurisprudential themes. Thus, Gene Dais, for example, in his treatment of Alberta's Universities Act, focuses on telling this story purposively.

Although the authors have largely concentrated their attention on the twenty-five year period celebrated by the University, few discernible patterns emerge because what has happened is as different and rich as the distinct subject matters involved. There has been dramatic, sweeping and progressive change in some areas and more incremental alteration in others. Two areas in which there has been significant change are presented in the work of Nick Rafferty and Patricia Rowbotham. Nick Rafferty outlines the emerging law of 
restitution and illustrates the major role played by the Supreme Court of Canada with its recognition of a generalized right to restitution based on the principle of unjust enrichment and its acceptance of the remedial constructive trust. Employing two case studies, Patricia Rowbotham traces the growth of public participation in the decisions of the Energy Resources Conservation Board. In some areas the impact and extent of certain legal developments has yet to be fully explored, appreciated and assimilated. It is in this latter frame of mind that my article questions what the rights entrenched and enshrined in the Canadian Charter of Rights and Freedoms may mean for how we approach laws which attempt to address sexual violence against women.

As you will witness, a great deal of energy, enthusiasm and perseverance went into the production of this collection. Special thanks are reserved for Nick Rafferty who coordinated and cajoled our efforts and for Richard Devlin who, along with Nick Rafferty, undertook the editorial functions.

I hope you enjoy these interesting articles and in so doing help us celebrate learning at the University of Calgary.

Sheilah Martin

Dean of Law

University of Calgary 